\title{
Section VI: Submarine Cables and Pipelines
}

\author{
Rule 67 \\ States, having laid submarine cables or pipelines, or whose nationals have \\ laid and operate such cables and pipelines, are entitled to take protective \\ measures with a view to preventing or terminating any harmful interference.
}

\section{Commentary}

1. The right of all States to lay submarine cables and pipelines in high sea areas and in the EEZ, and in the continental shelf of other States has been recognized by the international law of the sea.

2. The international law of the sea regulates the relations between coastal States and the States laying submarine cables and pipelines in a general manner, by distinguishing between the different sea areas. ${ }^{1}$ Articles 113 and 114 of UNCLOS deal with the breaking or injuring of a submarine cable or pipeline, and Article 115 provides for indemnity for loss incurred in avoiding injury to a submarine cable or pipeline.

3. However, UNCLOS is silent on certain aspects regarding submarine pipelines and cables and the question of whether and to what extent such cables and pipelines are subject to the jurisdiction of the States that own them or whose nationals have laid and operate them.

4. Article 113 of UNCLOS does not make it clear which other States also have jurisdiction over the breaking or injuring of submarine cables and pipelines beyond the territorial sea. It is, however, questionable whether only a flag State may exercise jurisdiction against foreigners regarding the breaking of cables or pipelines outside its own maritime zones.

\footnotetext{
${ }^{1}$ See the following provisions in UNCLOS, see fn. 58: Article 51(2)—archipelagic waters; Article 58(1)—EEZ; Article 79—continental shelf; Articles. 87(1) lit. (c), 112—high seas.
} 
5. Article 113 of UNCLOS merely deals with the obligation to penalise the breaking or injuring of submarine cables or pipelines by the flag State or the State of nationality of the perpetrator. This does not imply the exclusion of an exercise of jurisdiction in other than criminal matters. States have accepted the obligation to enact domestic criminal legislation because they agree that submarine cables and pipelines must be protected. Recognition of that obligation may not be considered a waiver of exercising jurisdiction in other matters or of taking the measures necessary to protect submarine cables and pipelines against malicious interference.

6. Hence, States having laid submarine cables and pipelines, or whose nationals have laid and/or operate them, may exercise their jurisdiction in accordance with well-established principles of international law, e.g., under the passive nationality and protective principle.

\section{Rule 68}

During an armed conflict, submarine pipelines and high voltage cables exclusively serving one or more Belligerent States may-if it is militarily necessary-be seized or destroyed subject to the applicable principles and rules of LOAC, in particular distinction, proportionality and the obligation to take feasible precautions.

\section{Commentary}

1. The supply of a Belligerent State with oil, gas and electricity may be crucial for war-fighting. Therefore, a Belligerent State may have a legitimate interest in denying the enemy such supply.

2. The traditional law of naval warfare is silent on submarine pipelines. Submarine telegraph cables are only addressed insofar as they are connecting occupied territory with neutral territory.

3. According to the Explanations in the San Remo Manual, "cables and pipelines exclusively serving one or more of the belligerents might be legitimate military objectives."2 Submarine cables and pipelines are not explicitly protected against seizure or destruction if they are connecting enemy territory, which is not occupied, with neutral territory.

4. A fortiori, this holds true for submarine cables exclusively serving one or more Belligerent States. Such cables and pipelines do not enjoy special protection from seizure or destruction. In the past, submarine cables were liable to seizure and destruction only when imperatively demanded by the necessity of the war. However, in view of the development of the law of naval warfare, this is lawful only if they qualify as lawful military objectives and if the basic principles and rules of the law of naval warfare are observed.

\footnotetext{
${ }^{2}$ San Remo Manual, see chapter "Section I: Outer Space”, fn. 29-Explanations, page 111.
} 


\section{Rule 69}

Submarine communications cables, whether or not connecting occupied territory with neutral territory, may not be seized or destroyed even if they are serving one or more Belligerent States. Belligerent States must take care to avoid damage to such cables, unless they qualify as lawful targets.

\section{Commentary}

1. This Rule is based on the San Remo Manual paragraph 37, see fn. 31.

2. The San Remo Manual provides that "[b]elligerents shall take care to avoid damage to cables and pipelines laid on the sea-bed which do not exclusively serve the belligerents."

3. Article 54 of the 1907 Hague Regulations and the provisions of the San Remo Manual seem to reflect correctly the lex lata insofar as submarine pipelines and submarine high voltage cables are concerned. If they qualify as lawful military objectives, they may be seized or destroyed, provided the principle of proportionality and the obligation to take feasible precautions are observed.

4. It is, however, doubtful whether the 1907 Hague Regulations and the San Remo provisions also apply to submarine communications cables. Other than telegraphic cables, modern submarine communications cables are the backbone of global data traffic. Although they may physically connect the territories of two States, it will only in rare circumstances be possible to determine that they are "exclusively serving one or more belligerents" or one or more Neutral States. Today's submarine communications cables are interconnected. Hence, data packages will travel over routes that are unpredictable. Accordingly, it is important to distinguish between submarine communications cables and other submarine cables.

\section{Rule 70}

Submarine pipelines and high voltage cables connecting occupied territory with neutral territory must not be seized or destroyed except in the case of absolute necessity. They must likewise be restored and compensation paid when peace is concluded.

\section{Commentary}

1. This Rule reflects customary international law insofar as submarine pipelines and high voltage cables are concerned. Article 54 of the 1907 Hague Regulations provides that submarine telegraph cables "shall not be seized or destroyed except in the case of absolute necessity" and that "they must likewise be restored and compensation fixed when peace is made."

2. The same logic applies to high voltage cables. This Rule does not apply to modern submarine communications cables dealt with in Rule 67. 
Open Access This chapter is licensed under the terms of the Creative Commons Attribution 4.0 International License (http://creativecommons.org/licenses/by/4.0/), which permits use, sharing, adaptation, distribution and reproduction in any medium or format, as long as you give appropriate credit to the original author(s) and the source, provide a link to the Creative Commons licence and indicate if changes were made.

The images or other third party material in this chapter are included in the chapter's Creative Commons licence, unless indicated otherwise in a credit line to the material. If material is not included in the chapter's Creative Commons licence and your intended use is not permitted by statutory regulation or exceeds the permitted use, you will need to obtain permission directly from the copyright holder. 